Original Article

\title{
Morphophysiological changes of Acca sellowiana (Myrtaceae: Myrtoideae) saplings under shade gradient
}

\author{
Alterações morfofisiológicas em mudas de Acca sellowiana (Myrtaceae: Myrtoideae) \\ sob gradiente de sombreamento
}

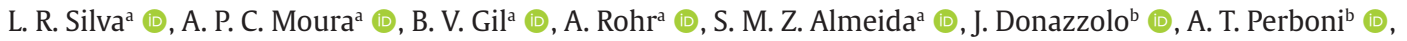

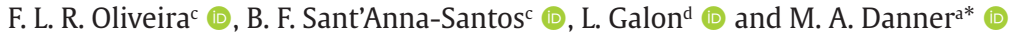 \\ aUniversidade Tecnológica Federal do Paraná - UTFPR, Câmpus Pato Branco, Programa de Pós-Graduação em Agronomia, Pato Branco, Paraná, \\ Brasil \\ bUniversidade Tecnológica Federal do Paraná - UTFPR, Câmpus Dois Vizinhos, Programa de Pós-Graduação em Agroecossistemas, Dois \\ Vizinhos, Paraná, Brasil \\ 'Universidade Federal do Paraná - UFPR, Departamento de Botânica, Curitiba, Paraná, Brasil \\ dUniversidade Federal da Fronteira Sul - UFFS, Câmpus Erechim, Programa de Pós-Graduação em Ciência e Tecnologia Ambiental, Erechim, Rio \\ Grande do Sul, Brasil
}

\begin{abstract}
Understanding morphological and physiological changes under different light conditions in native fruit species in juveniles' stage is important, as it indicate the appropriate environment to achieve vigorous saplings. We aimed to verify growth and morphophysiological changes under shade gradient in feijoa (Acca sellowiana (O. Berg) Burret) to achieve good quality saplings adequate to improve cultivation in orchards. The saplings were grown for twenty-one-month under four shading treatments (0\%,30\%,50\%, and $80 \%$ ). Growth, photosynthetic pigments, gas exchanges, chlorophyll fluorescence, and leaf anatomy parameters were evaluated. Saplings under full sun and 30\% shade had higher height and diameter growth and dry mass accumulation due to higher photosynthesis rate. As main acclimatization mechanisms in feijoa saplings under $80 \%$ shade were developed larger leaf area, reduced leaf blade thickness, and enhanced quantum yield of photosystem II. Even so, the net $\mathrm{CO}_{2}$ assimilation and the electron transport rate was lower and, consequently, there was a restriction on the growth and dry mass in saplings under deep shade. Therefore, to obtain higher quality feijoa saplings, we recommend that it be carried out in full sun or up to $30 \%$ shade, to maximize the sapling vigor in nurseries and, later, this light environment can also be used in orchards for favor growth and fruit production.
\end{abstract}

Keywords: acclimatization, leaf anatomy, photosynthesis, native fruits, Brazilian guava.

\begin{abstract}
Resumo
A verificação de mudanças morfológicas e fisiológicas sob diferentes condições luminosas em espécies frutíferas nativas em estágio juvenil é importante, uma vez que indicam o ambiente adequado para a formação de mudas com alto vigor. Objetivou-se verificar o crescimento e as alterações morfofisiológicas sob gradiente de sombreamento em mudas de feijoa (Acca sellowiana (O. Berg) Burret) para obter mudas de boa qualidade, adequadas para fomentar os plantios da espécie em pomares. As mudas foram cultivadas por vinte e um meses sob quatro tratamentos de sombreamento ( $0 \%, 30 \%, 50 \%$ e $80 \%)$. Foram avaliados parâmetros de crescimento, pigmentos fotossintéticos, trocas gasosas, fluorescência da clorofila e anatomia foliar. Mudas a pleno sol e 30\% de sombra apresentaram maior crescimento em altura, diâmetro e acúmulo de massa seca, devido à maior taxa de fotossíntese. Como principais mecanismos de aclimatação sob 80\% de sombra, as mudas desenvolveram maior área foliar, redução da espessura do limbo foliar e aumento do rendimento quântico do fotossistema II. Mesmo assim, a assimilação líquida de $\mathrm{CO}_{2} \mathrm{e}$ a taxa de transporte de elétrons foram menores e, consequentemente, houve restrição ao crescimento e acúmulo de massa seca das mudas no maior nível de sombreamento. Portanto, para a obtenção de mudas de feijoa de maior qualidade, recomendamos que seja realizada a pleno sol ou até $30 \%$ de sombra, para maximizar o vigor das mudas em viveiros e, posteriormente, este ambiente de luz também pode ser utilizado em pomares para favorecer o crescimento e a produção de frutos.
\end{abstract}

Palavras-chave: aclimatização, anatomia foliar, fotossíntese, frutas nativas, goiabeira serrana.

*e-mail: moesesdanner@utfpr.edu.br

Received: May 19, 2021 - Accepted: October 6, 2021

This is an Open Access article distributed under the terms of the Creative Commons Attribution License, which permits unrestricted use, distribution, and reproduction in any medium, provided the original work is properly cited. 


\section{Introduction}

Feijoa or Brazilian guava [Acca sellowiana (O. Berg) Burret, Myrtaceae: Myrtoideae] is a fruit tree native to Southern Brazil and Northern Uruguay (Moretto et al., 2014). There are two botanical types for the species, the "Uruguai" type, occurring in the Pampa biome in low-altitude areas, and the "Brasil" type occurring in the Atlantic Forest biome (Ducroquet et al., 2000), typically in "capões" (small forest stands) with Araucaria angustifolia at 900 to $1300 \mathrm{~m}$ a.s.l. (Lorenzini et al., 2007). This species is a source of food for several wild animals in the plateaus of Southern Brazil (Bogoni et al., 2018). Also, humans have been managing it for a long time for fruit consumption (Santos et al., 2018; Donazzolo et al., 2020). Its fruit has antibacterial, anti-inflammatory, antioxidant, and antiallergic activity due to the high concentration of flavonoid (Zhu, 2018) and has a unique sweet-acidic flavor that made it attractive for cultivation and consumption (Sun-Waterhouse et al., 2013).

In Brazil, there are no official feijoa production and consumption statistics available, but some sources indicate that Brazil has imported feijoa fruits from Colombia, which had the world's largest production, following by New Zealand. Both countries developed varieties based on seeds obtained from Brazil many decades ago, while only in recent decades, Brazilian cultivation has been encouraged through plant breeding and on-farm management (Moretto et al., 2014; Santos et al., 2017). Although there are already four varieties of feijoa, named Alcântara, Helena (Ducroquet et al., 2007), Mattos and Nonante (Ducroquet et al., 2008), feijoa cultivation is small-scale in Brazil, largely due to the lack of good quality saplings (Gomes et al., 2016).

Obtaining good quality saplings of selected genotypes is crucial to improve cultivation of feijoa. Thus, it is essential to study the morphophysiological adjustments to the shade of feijoa saplings to define the appropriate light conditions to achieve good quality saplings production and beyond, i.e. their growth and fruit production in orchards. This is because plants under different light conditions may demonstrate plasticity throughout little or larger complex effects, such as morphological and physiological changes, which could acclimatize saplings to be more efficient in light uptake and use in photosynthesis, carbon accumulation, growth and survival (Valladares and Niinemets, 2008). In the plateau of South Brazil, feijoa trees occurs balanced both in the border and at shade in Araucaria small forest stands (Lorenzini et al., 2007), and also there are feijoa in Pampa biome (Ducroquet et al., 2000), which grasslands scattered with shrubs and sparse trees are the dominant vegetation (Roesch et al., 2009). Therefore, we hypothesize that feijoa saplings will have their grown favored under high light availability, although they could have changes in leaves anatomy and photosynthesis apparatus, indicating their shade tolerance in juveniles' stage.

We aimed to verify growth and morphophysiological changes under shade gradient of feijoa (Acca sellowiana (O. Berg) Burret) to obtain good quality saplings adequate to improve cultivation in orchards.

\section{Material and Methods}

Seeds collected from one selected feijoa tree, nearing some other ones distributed in an urban backyard from Vacaria city, Rio Grande do Sul, Brazil (28³0' S; 5056' W; $960 \mathrm{~m}$ a.s.l.) were used for the seedlings production. The seedlings were grown in pots $(2.0 \mathrm{~L})$ in a nursery with $50 \%$ shade until twelve-month-old. The saplings were transplanted into larger pots $(40.0 \mathrm{~L})$ filled with a mixture of soil, commercial substrate, and vermiculite ( $3: 1.5: 0.5$; v: v: v) and submitted to different light levels: full sun, and $30 \%, 50 \%$, and $80 \%$ shade, with 12 replications (sapling in one pot) of each treatment. The shading environments were built with wood structures $3.0 \mathrm{~m}$ tall, completely surrounded by black mesh screens of each respective shade level. The plants received daily irrigation, monthly manual weed control, and two fertilizations with $20 \mathrm{~g}$ per plant of NPK formulation (8-28-16), at 12 and 18 months after transplantation, and at 21 months all evaluations were performed in juveniles' plants.

The saplings growth evaluation was performed by the difference between the height and diameter measured at the transplantation and at 21 months of the experiment. The total number of leaves was counted, and the leaf area was measured using the LI-3100 meter (Li-Cor, Inc.) in 100 leaves of four plants for each treatment. Roots and shoots of each plant were dried in an oven at $60{ }^{\circ} \mathrm{C}$ until they reached a constant mass, obtaining the root and the shoot dry matter. Dickson's quality index (DQI) $=$ [total dry matter/(RSD+RSR)] was calculated, where RSD is the ratio between height and diameter, and RSR is the ratio between shoot and root dry matter (Dickson et al., 1960).

Photosynthetic pigments (chlorophyll $a$, chlorophyll $b$, and carotenoids) from two leaves of 12 plants per treatment were analyzed. Two discs of $0.6 \mathrm{~cm}$ in diameter were removed from each leaf, immersed in $5.0 \mathrm{~mL}$ of dimethyl sulfoxide (DMSO) and kept in the dark in a water bath at $65{ }^{\circ} \mathrm{C}$ until they were translucent ( 18 hours). After that, the absorbance readings were carried out on a UV/VIS spectrophotometer (Shimadzu model UV-1800) at $480 \mathrm{~nm}$ (carotenoids), $649.1 \mathrm{~nm}$ (chlorophyll $a$ ), and $665.1 \mathrm{~nm}$ (chlorophyll $b$ ) and calculated the concentrations of each pigment (Wellburn, 1994).

Gas exchanges were evaluated using the infrared gas analyzer (IRGA) model LC-pro (ADC BioScientific Ltda., UK), between 9:00 am and 11:00 am on a sunny day. Three fully expanded leaves were evaluated in five plants per treatment. Photosynthetically active radiation (PAR), net $\mathrm{CO}_{2}$ assimilation rate $(\mathrm{A})$, transpiration rate $(\mathrm{E})$, stomatal conductance (Gs), and intracellular $\mathrm{CO}_{2}$ concentration (Ci) were evaluated. The instantaneous carboxylation efficiency (EiC) was established through the relationship between $\mathrm{A} / \mathrm{Ci}$.

Chlorophyll fluorescence was determined using a fluorometer (Multi-ModeChlorophyll Fluorometer ${ }^{\circledR}$, Model OS5p). The evaluations were done between 9:00 am and 11:00 am on a sunny day on three leaves of five plants per treatment. Each sample was exposed to a pulse of light saturation, obtaining the results of initial fluorescence (F'), maximum fluorescence (Fm), maximum quantum yield 
of photosystem II [Y(II)], and relative electron transport rate (ETR).

Also, three leaves were collected from four plants per treatment for anatomy analysis, which were fixed in $\mathrm{FAA}_{50}$ (formaldehyde, acetic acid, 50\% ethanol, 1: 1: 18 , v: v: v) for $24 \mathrm{~h}$, washed in $50 \%$ ethanol and stored in $70 \%$ ethanol (Johansen, 1940). The samples were cut into $0.5 \mathrm{~cm}^{2}$ fragments in the central part of the leaf blade, dehydrated with a graded series of ethanol $(80 \%, 90 \%$, and $95 \%$ ), and embedded in methacrylate (Historesina, Leica Instruments). Cross-sections with $8.0 \mu \mathrm{m}$ thickness were obtained, stained in toluidine blue $(0.12 \%)$, and mounted on a slide and coverslip by using glass varnish. The images' digitalization was performed in a photomicroscope (Zeiss Axiolab) with a digital camera attached (Sony Cybershot $7.2 \mathrm{mb}$ ). Using the ANATI QUANTI software (Aguiar et al., 2007), the thickness of the abaxial and adaxial epidermis, spongy and palisade parenchyma, and limbus were measured with nine replications per sample.

The data were subjected to the normality (Shapiro Wilk) and the homoscedasticity test (Bartlett). Box-Cox transformation was used when necessary, followed by variance analysis in a completely random design and the Scott-Knott clustering test were applied. All analyzes were processed on the R platform ( $\mathrm{R}$ Development Core Team, 2020).
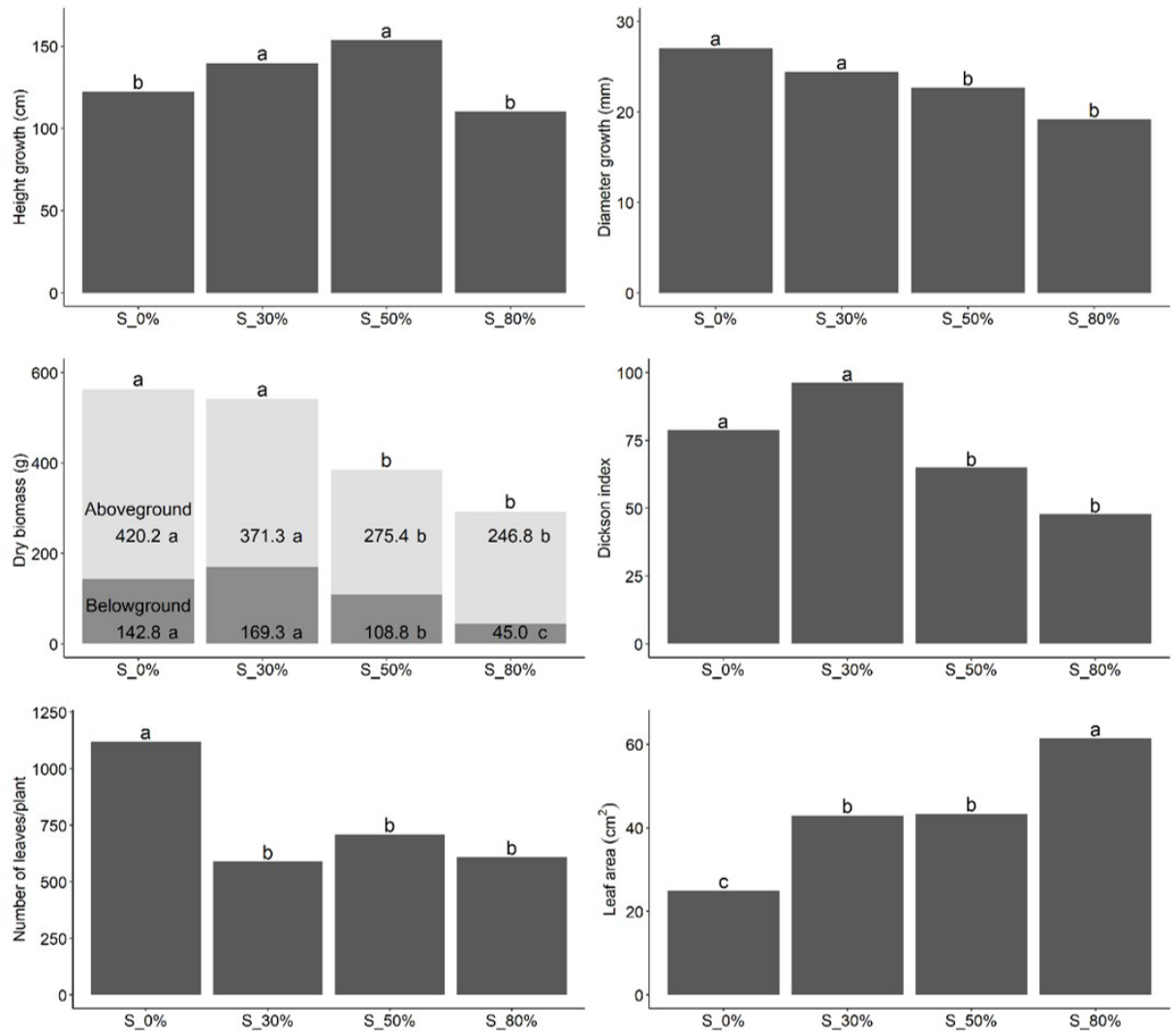

Figure 1. Growth parameters of Acca sellowiana saplings under shade gradient, in full sun (S_0\%) and 30\% (S_30\%), 50\% (S_50\%) and $80 \%$ (S_80\%) shade. Leaf area and number of leaves data were transformed by BoxCox. Bars represent the averages of each treatment and containing different letters differ from each other by the Scott-Knott test $(\mathrm{p} \leq 0.05)$. 


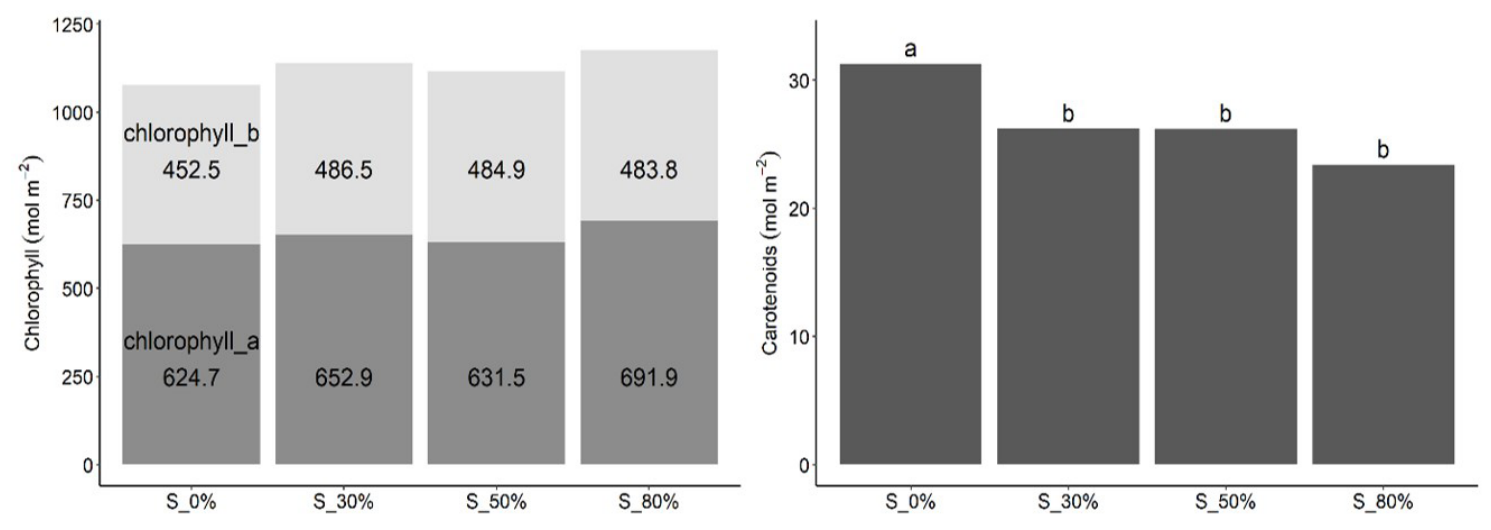

Figure 2. Photosynthetic pigments content of Acca sellowiana leaves under shade gradient, in full sun (S_0\%) and 30\% (S_30\%), 50\% (S_50\%) and 80\% (S_80\%) shade. Bars represent the averages of each treatment and containing different letters differ from each other by the Scott-Knott test $(p \leq 0.05)$.

transpiration rate (E), stomatal conductance (Gs), and carboxylation efficiency (EiC). This indicates that the restriction of $\sim 30 \%$ of photosynthetically active radiation (PAR) on the feijoa did not have a significant effect on photosynthesis reduction. However, the limitation of $\sim 50$ and $~ 80 \%$ of PAR significantly reduced gas exchanges, and this explains the lower dry mass accumulation in feijoa saplings under these light conditions. The intercellular $\mathrm{CO}_{2}$ concentration $(\mathrm{Ci})$ was higher in the seedlings under $50 \%$ and $80 \%$ shade, indicating that most of the $\mathrm{CO}_{2}$ absorbed is not used by the photosystem due to the low PAR (see Figure 3).

Higher values of initial fluorescence (F'), maximum fluorescence $(\mathrm{Fm})$, and quantum yield of photosystem II [Y(II)] were found in the saplings under $80 \%$ shade. However, the electron transport rate (ETR) was higher in ones under full sun and 30\% shade (see Figure 4), which shows that the low luminosity restricted photosynthesis in the saplings under higher intensity of shade. Although light has been used more efficiently (greater [Y(II)]) the scarcity of light in the $80 \%$ shade treatment drastically reduced the electrons transported (lower ETR) and, probably, caused the reduction of the final acceptors in the electron transport chain, compared to other treatments.

Except for the spongy parenchyma, the other leaf tissues showed a significant thickness reduction following the increase of shade, mainly under $50 \%$ and $80 \%$ shade (see Figure 5).

However, there were no qualitative changes in the composition and organization of the leaves cellular structure under different shade levels (see Figure 6).

\section{Discussion}

For the first time we submit feijoa saplings to shade gradient and measure various morphophysiological changes aiming to achieve good quality saplings. We verified that more shoot and root dry mass accumulation were observed in feijoa saplings under full sun and $30 \%$ shade. This indicates that high luminosity is required by this species, providing an increase in photosynthesis and, consequently, higher carbon accumulation (Sherzad et al., 2017). The Dickson's Quality Index was higher in the saplings under full sun and 30\% shade, which means the best quality was found under these light environments. This is because plants were more vigorous, indicating a greater balance of growth and development in height and diameter and the allocation of dry mass between shoot and root (Dickson et al., 1960). On the other hand, submitting Acca sellowiana saplings to low light availability restricted $\mathrm{CO}_{2}$ assimilation and carbohydrate production, resulting in reduced plant growth and development under $50 \%$ and $80 \%$ shade, because despite having larger leaves, they had a smaller number of leaves.

Feijoa saplings under $50 \%$ and $80 \%$ shade had lower stomatal conductance and accumulated higher concentration of intercellular carbon, due to the low rate of $\mathrm{CO}_{2}$ assimilation. The limited availability of light caused losses in the photochemical phase of photosynthesis, which was marked by the low rate of electron transport when compared to other treatments, which may have reduced the production of ATP and NAPDH for the biochemical phase of photosynthesis (Valladares and Niinemets, 2008; Huang et al., 2011). This led to a reduction in biomass production, even though plants under $80 \%$ shading have shown phenotypic and biochemical plasticity by increasing leaf area and Y(II) trying to increase light capture. Besides, even though the increase in total chlorophyll content to be a response often observed in plants to compensate little available light (Dai et al., 2009), this acclimatization mechanism does not occur in feijoa in our work, and either to other fruit plant species, such as olive trees (Ajmi et al., 2018), although this effect in chlorophyll content can be differentiated in early and late successional species (Portes et al., 2010).

The development of thicker leaves with a higher proportion of palisade parenchyma in feijoa saplings under high light intensity was a mechanism to increase the use of available light, a strategy associated with species nontolerant to shading. The greater thickness of the epidermis of leaves exposed to greater luminosity indicates that 

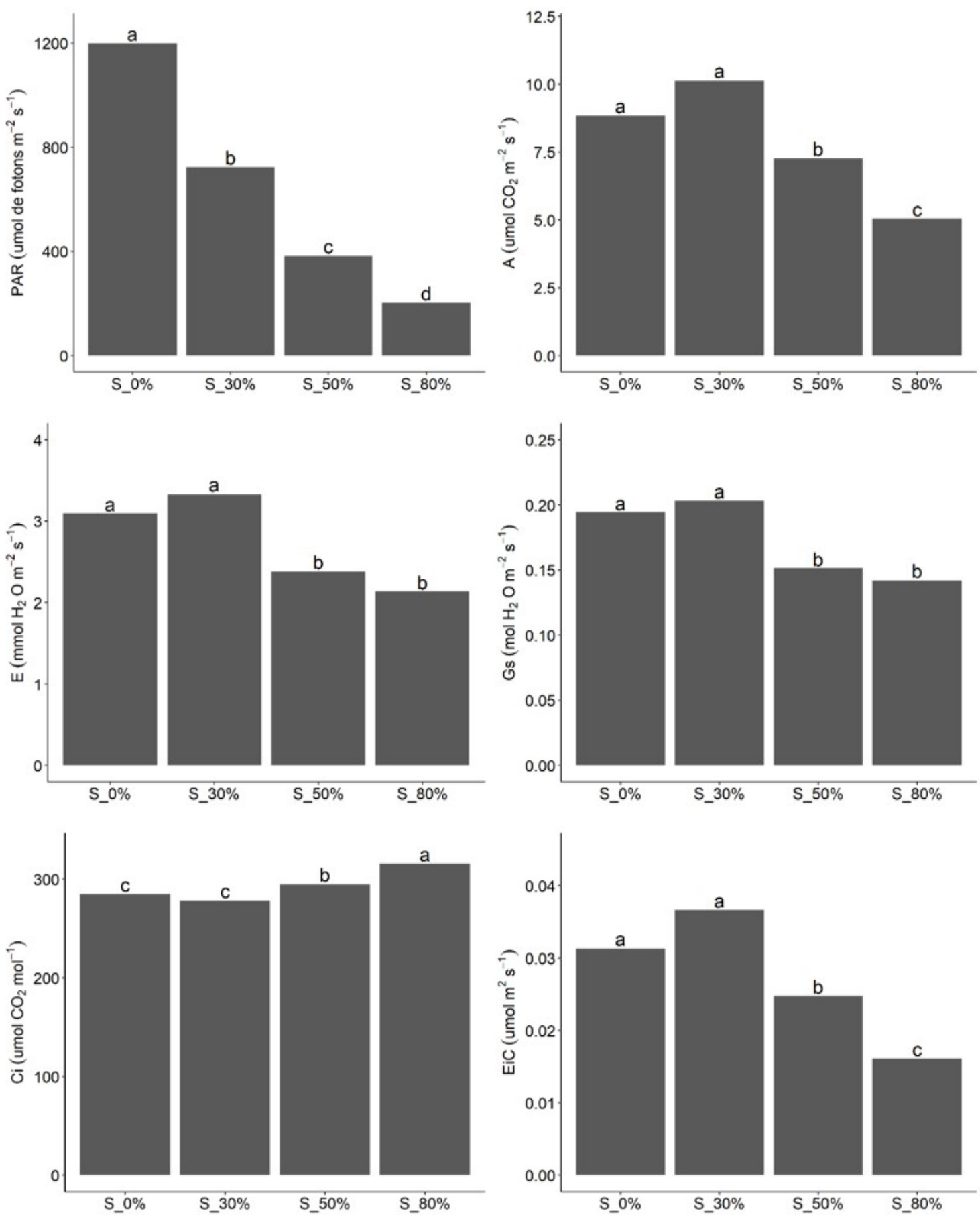

Figure 3. Gas exchange parameters of Acca sellowiana leaves under shade gradient, in full sun (S_0\%) and 30\% (S_30\%), 50\% (S_50\%) and $80 \%\left(\mathrm{~S} \_80 \%\right)$ shade. Ci data were transformed by BoxCox. Bars represent the averages of each treatment and containing different letters differ from each other by the Scott-Knott test $(p \leq 0.05)$. Photosynthetically active radiation (PAR); net $\mathrm{CO}_{2}$ assimilation rate (A); transpiration rate (E); stomatal conductance (Gs); intercellular $\mathrm{CO}_{2}$ concentration (Ci); and carboxylation efficiency (EiC).

this is performed as a protective barrier against excess irradiation. In contrast, the greater reduction in the epidermis thickness in the leaves under $50 \%$ and $80 \%$ shade indicates that the leaves reduced energy investment in this tissue to maximize the light uptake (Craven et al., 2010).
The increase in the carotenoid concentration associated with the greater thickness of the leaves of feijoa saplings under full sun indicates mechanisms developed for the photoprotection of photosynthetic apparatus. Carotenoid pigments dissipate the excess energy that could cause 

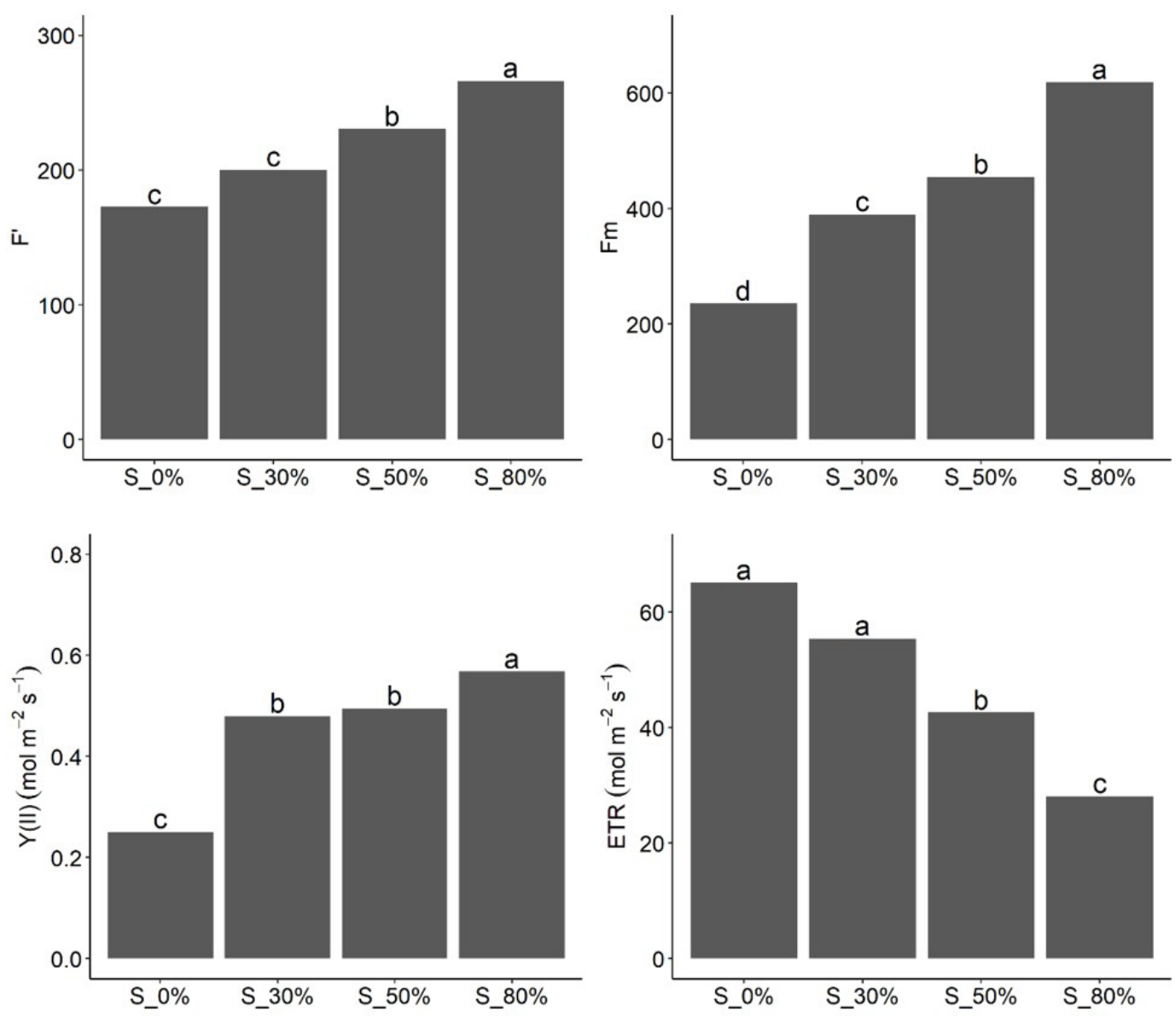

Figure 4. Fluorescence of chlorophyll parameters from Acca sellowiana leaves under shading gradient, in full sun (S_0\%) and 30\% (S_30\%), $50 \%$ (S_50\%) and 80\% (S_80\%) shade. Bars represent the averages of each treatment and containing different letters differ from each other by the Scott-Knott test $(p \leq 0.05)$. Initial fluorescence (F'); maximum fluorescence (Fm); quantum yield of photosystem II (Y(II)); and electron transport rate (ETR).

damage to photosystem II, throughout the interconversion of violaxanthin to zeaxanthin in the xanthophyll cycle (Goh et al., 2012). If an increase in fluorescence would be observed, this could indicate damage to the reaction centers of photosystem II or a reduction in the electron transport rate (Baker, 2008). The decrease in the effective quantum yield of photosystem II [Y(II)] in feijoa saplings under full sun indicates that part of the absorbed light was not converted into photochemical energy and, therefore, was dissipated as heat (Anjos et al., 2012). Despite the excess energy dissipation mechanisms, the high electron transport rate of plants in response to higher incident radiation is indicative of the high capacity to allocate the excitation energy captured by photosystems to the linear flow of electrons in photochemistry, featuring greater efficiency the use of light energy (Calzavara et al., 2017).

Furthermore, the net $\mathrm{CO}_{2}$ assimilation rate $(\mathrm{A})$ values of plants grown under the sun and $30 \%$ of shading (see Figure 3) confirm that the increased levels of ETR were fundamental for the $\mathrm{CO}_{2}$ fixation process and, consequently, for the accumulation of biomass. On the other hand, the increase in Y(II) and the lower ETR in saplings under

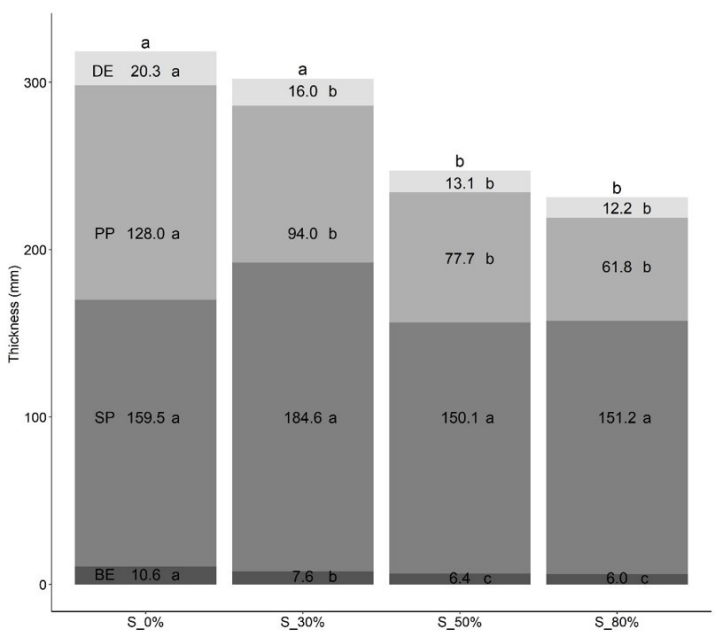

Figure 5. Thickness of foliar portions of Acca sellowiana leaves under full sun(S_0\%) and 30\%(S_30\%), 50\%(S_50\%) and 80\%(S_80\%) shade. Averages followed by different letters differ from each other by the Scott-Knott test $(p \leq 0.05)$. BE: abaxial epidermis; SP: spongy parenchyma; PP: palisade parenchyma; DE: adaxial epidermis. 

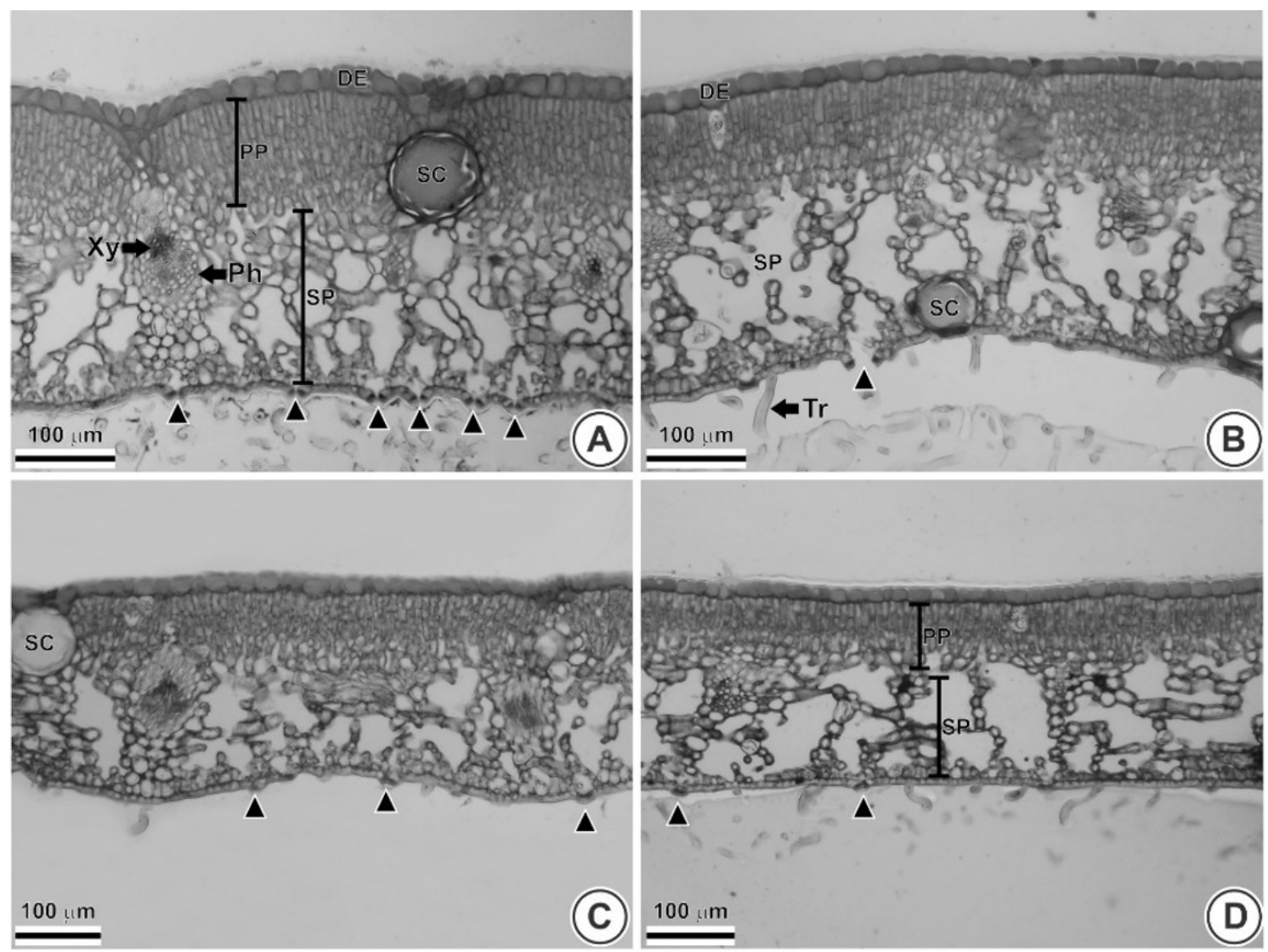

Figure 6. Structural leaf anatomy of Acca sellowiana saplings under full sun (S_0\%) and 30\%(S_30\%), 50\% (S_50\%) and 80\% (S_80\%) shade. Full sun (A), 30\% (B), 50\% (C) and 80\% (D) shade. DE (adaxial epidermis); Xy (xylem); Ph (phloem); SC (Secretory cavities); PP (palisade parenchyma); SP (Spongy parenchyma); Tricome (Tr); arrowhead (stomatas).

$80 \%$ shade indicates that although little light reached the photosystems, much of it was being captured by the reaction centers and used in photosynthesis (Wang and Bauerle, 2006).

Feijoa saplings had greater growth under full sun and $30 \%$ shade due to the higher photosynthesis rate. However, there were anatomical and physiological adjustments in the feijoa saplings under 50 and $80 \%$ shade, demonstrating the species' phenotypic plasticity to survive and grow under these conditions in juveniles' stage. It is essential to highlight that the increase in leaf area and leaf thickness reduction is related to increases in the light interception, consequently improving the effective quantum yield of photosystem II. This aspect supports the species' occurrence both in border and below canopy of Araucaria forest (Lorenzini et al., 2007) and in Pampa (no forest biome) (Ducroquet et al., 2000). Besides that, the production of saplings in nurseries and orchards of this species should be under high light environments, because it makes saplings more vigorous and can anticipate and improve fruit production. However, new researches using several genotypes must be encouraged, because our work was made assess only one feijoa progenies, i.e. seeds are half-sibs, and mother-tree grew in full sun environment.

\section{Conclusion}

We recommended that feijoa (Acca sellowiana) saplings production be carried out under full sun or up to $30 \%$ shade, because it turned into more vigorous. Under the high intensity of shade (50\% and $80 \%$ ), there were morphophysiological changes such as increase of leaf area, reduction in leaf thickness, and increase quantum yield of photosystem II, acting as mechanisms of acclimatization. However, there was a marked reduction in biomass accumulation and photosynthesis, reducing the saplings quality under this low light environment, that can be negative implicate in future fruit production in orchards.

\section{Acknowledgements}

We gratefully acknowledge the CAPES, Fundação Araucária, and CNPq for research support.

\section{References}

AGUIAR, T.V., SANT'ANNA-SANTOS, B.F., AZEVEDO, A.A. and FERREIRA, R.S., 2007. Anati Quanti: software de análises quantitativas para estudos em anatomia vegetal. Planta Daninha, 
vol. 25, no. 4, pp. 649-659. http://dx.doi.org/10.1590/S010083582007000400001.

AJMI, A., VÁZQUEZ, S., MORALES, F., CHAARI, A., EL-JENDOUBI, H., ABADÍA, A. and LARBI, A., 2018. Prolonged artificial shade affects morphological, anatomical, biochemical and ecophysiological behavior of young olive trees (cv. Arbosana). Scientia Horticulturae, vol. 241, pp. 275-284. http://dx.doi. org/10.1016/j.scienta.2018.06.089.

ANJOS, L., OLIVA, M.A. and KUKI, K.N., 2012. Fluorescence imaging of light acclimation of Brazilian Atlantic forest tree species. Photosynthetica, vol. 50, no. 1, pp. 95-108. http://dx.doi. org/10.1007/s11099-012-0018-6.

BAKER, N.R., 2008. Clorophyll fluorescence: a probe of photosynthesis in vivo. Annual Review of Plant Biology, vol. 59, no. 1, pp. 89-113. http://dx.doi.org/10.1146/annurev. arplant.59.032607.092759. PMid:18444897.

BOGONI, J., GRAIPEL, M. and PERONI, N., 2018. The ecological footprint of Acca sellowiana domestication maintains the residual vertebrate diversity in threatened highlands of Atlantic Forest. PLoS One, vol. 13, no. 4, pp. e0195199. http://dx.doi.org/10.1371/ journal.pone.0195199. PMid:29617455.

CALZAVARA, A.K., ROCHA, J.S., LOURENÇO, G., SANADA, K., MEDRI, C., BIANCHINI, E., PIMENTA, J.A., STOLF-MOREIRA, R. and OLIVEIRA, H.C., 2017. Acclimation responses to high light by Guazuma ulmifolia Lam. (Malvaceae) leaves at different stages of development. Plant Biology, vol. 19, no. 5, pp. 720-727. http:// dx.doi.org/10.1111/plb.12592. PMid:28637094.

CRAVEN, D., GULAMHUSSEIN, S. and BERLYN, G.P., 2010. Physiological and anatomical responses of Acacia koa (Gray) seedlings to varying light and drought conditions. Environmental and Experimental Botany, vol. 69, no. 2, pp. 205-213. http://dx.doi. org/10.1016/j.envexpbot.2010.04.002.

DAI, Y., SHEN, Z., LIU, Y., WANG, L., HANNAWAY, D. and LU, H., 2009. Effects of shade treatments on the photosynthetic capacity, chlorophyll fluorescence, and chlorophyll content of Tetrastigma hemsleyanum Diels et Gilg. Environmental and Experimental Botany, vol. 65, no. 2-3, pp. 177-182. http://dx.doi. org/10.1016/j.envexpbot.2008.12.008.

DICKSON, A., LEAF, A.L. and HOSNER, J.F., 1960. Quality appraisal of white spruce and white pine seedling stock in nurseries. Forestry Chronicle, vol. 36, no. 1, pp. 10-13. http://dx.doi. org/10.5558/tfc36010-1.

DONAZZOLO, J., STEFENON, V.M., GUERRA, M.P. and NODARI, R.O., 2020. On farm management of Acca sellowiana (Myrtaceae) as a strategy for conservation of species genetic diversity. Scientia Horticulturae, vol. 259, no. 3, pp. 108826. http://dx.doi. org/10.1016/j.scienta.2019.108826.

DUCROQUET, J.P.H.J., HICKEL, E.R. and NODARI, R.O. 2000. Goiabeira serrana (Feijoa sellowiana). Jaboticabal: FUNEP. 66 p.

DUCROQUET, J.P.H.J., NUNES, E.C., GUERRA, M.P. and NODARI, R.O., 2008. Novas cultivares brasileiras de goiabeira-serrana: SCS 414-Mattos e SCS 415-Nonante. Agropecuária Catarinense, vol. 21, pp. 79-82.

DUCROQUET, J.P.H.J., SANTOS, K.L., ANDRADE, E.R., BONETI, J.I., BONIN, V. and NODARI, R.O., 2007. As primeiras cultivares brasileiras de goiabeira serrana: SCS 411 Alcântara e SCS 412 Helena. Agropecuária Catarinense, vol. 20, pp. 77-80.

GOH, C.-H., KO, S.-M., KOH, S., KIM, Y.-J. and BAE, H.-J., 2012. Photosynthesis and environments: photoinhibition and repair mechanisms in plants. Journal of Plant Biology, vol. 55, no. 2, pp. 93-101. http://dx.doi.org/10.1007/s12374-011-9195-2.

GOMES, J.P., OLIVEIRA, L.M., FERREIRA, P.I. and BATISTA, F., 2016. Substratos e temperaturas para teste de germinação em sementes de Myrtaceae. Ciência Florestal, vol. 26, no. 1, pp. 285-293. http://dx.doi.org/10.5902/1980509821120.

HUANG, D., WU, L., CHEN, J.R. and DONG, L., 2011. Morphological plasticity, photosynthesis e chlorophyll fluorescence of Athyrium pachyphlebium at different shade levels. Photosynthetica, vol. 49, no. 4, pp. 611-618. http://dx.doi.org/10.1007/s11099-011-0076-1.

JOHANSEN, D.A. 1940. Plant microtechnique. New York: McGrawHill. 790 p.

LORENZINI, A.R., BOFF, M.I.C., RECH, T.D. and BOFF, P., 2007. Fitogeografia da goiabeira serrana no Planalto Serrano Catarinense. Agropecuária Catarinense, vol. 20, pp. 86-89.

MORETTO, S.P., NODARI, E.S. and NODARI, R.O., 2014. A introdução e os usos da feijoa ou goiabeira-serrana (Acca sellowiana): A perspectiva da história ambiental. Journal of Social. Technological and Environmental Science, vol. 3, no. 2, pp.67-79. http://dx.doi. org/10.21664/2238-8869.2014v3i2.p67-79.

PORTES, M.T., DAMINELI, D.S.C., RIBEIRO, R.V., MONTEIRO, J.A.F. and SOUZA, G.M., 2010. Evidence of higher photosynthetic plasticity in the early successional Guazuma ulmifolia Lam. compared to the late successional Hymenaea courbaryl L. grown in contrasting light environments. Brazilian Journal of Biology = Revista Brasileira de Biologia, vol. 70, no. 1, pp. 75-83. http:// dx.doi.org/10.1590/S1519-69842010000100011. PMid:20231962.

R DEVELOPMENT CORE TEAM 2020 [viewed 20 June 2020]. R: A language and environment for statistical computing [online]. Available from: https://www.R-project.org/.

ROESCH, L.F.W., VIEIRA, F.C.B., PEREIRA, V.A., SCHÜNEMANN, A.L., TEIXEIRA, I.F., SENNA, A.J.T. and STEFENON, V.M., 2009. The Brazilian Pampa: a fragile Biome. Diversity, vol. 1, no. 2, pp. 182-198. http://dx.doi.org/10.3390/d1020182.

SANTOS, K.L., CIOTTA, M.N. and NODARI, R.O., 2017. Melhoramento genético da goiabeira-serrana (Acca sellowiana) em Santa Catarina. Agropecuária Catarinense, vol. 30, pp. 40-42.

SANTOS, K.L., DONAZZOLO, J., GURIES, R.P., PERONI, N. and NODARI, R.O., 2018. Participatory research with Acca sellowiana: stimulating the breeding process for a native fruit species. Agroecology and Sustainable Food Systems, vol. 42, no. 4, pp. 432-447. http://dx.doi.org/10.1080/21683565.2017.1373383.

SHERZAD, O.H., ZAKI, H.M. and HAZANDY, A.H., 2017. Effect of different shade periods on Neobalanocarpus heimii seedlings biomass and leaf morphology. Journal of Tropical Forest Science, vol. 29, no. 4, pp. 457-464. http://dx.doi.org/10.26525/ jtfs2017.29.4.457464.

SUN-WATERHOUSE, D., WANG, W., WATERHOUSE, G.I.N. and WADHWA, S.S., 2013. Utilisation potential of feijoa fruit wastes as ingredients for functional foods. Food and Bioprocess Technology, vol. 6, no. 12, pp. 3441-3455. http://dx.doi.org/10.1007/s11947012-0978-3.

VALLADARES, F. and NIINEMETS, Ü., 2008. Shade tolerance, a key plant feature of complex nature and consequences. Annual Review of Ecology Evolution and Systematics, vol. 39, no. 1, pp. 237257. http://dx.doi.org/10.1146/annurev.ecolsys.39.110707.173506.

WANG, G.G. and BAUERLE, W.L., 2006. Effects of light intensity on the growth and energy balance of photosystem II electron transport in Quercus alba seedlings. Annals of Forest Science, vol. 63, no. 2, pp. 111-118. http://dx.doi.org/10.1051/forest:2005103.

WELLBURN, A.R., 1994. The spectral determination of chlorophylls a and $b$, as well as total carotenoids, using various solvents with spectrophotometers of different resolution. Journal of Plant Physiology, vol. 144, no. 3, pp. 307-313. http://dx.doi. org/10.1016/S0176-1617(11)81192-2.

ZHU, F., 2018. Chemical and biological properties of feijoa (Acca sellowiana). Trends in Food Science \& Technology, vol. 81, pp. 121-131. http://dx.doi.org/10.1016/j.tifs.2018.09.008. 